\title{
FAKTOR-FAKTOR YANG BERHUBUNGAN DENGAN STRES KERJA PADA PEKERJA DIVISI BUSINESS SOLUTION, SUPPORT DAN SERVICE DELIVERY PT ADMINISTRASI MEDIKA JAKARTA
}

\author{
Muhammad Nurcholis Wicaksono ${ }^{1}$, Inggit Meliana Anggarini ${ }^{2}$ \\ ${ }^{1 *}$ PT. Administrasi Medika Jakarta \\ ${ }^{2}$ Program studi S1 Kesehatan Masyarakat Universitas MH. Thamrin \\ olis.wicaksono@gmail.com
}

\begin{abstract}
ABSTRAK
Stres kerja merupakan gangguan fisik dan emosional sebagai akibat ketidaksesuaian antara kapabilitas, sumber daya atau kebutuhan pekerja yang berasal dari lingkungan pekerjaan. Stress kerja memiliki dampak yang beragam yang dapat mempengaruhi kesehatan pekerja maupun performa perusahaan. Oleh karena itu, Peneliti melakukan penelitian faktorfaktor yang berhubungan dengan stress kerja pada pekerja Divisi Business Solution, Support, \& Service Delivery di AdMedika Jakarta tahun 2017. Penelitian ini merupakan penelitian deskriptif analitik dengan desain cross sectional. Sampel penelitian berjumlah 31 orang. Pengambilan sampel dilakukan dengan metode total sampling. Berdasarkan hasil penelitian, terdapat $23(74,2 \%)$ dari 31 pekerja yang mengalami gejala stress. Meskipun jumlah pekerja relatif cukup tinggi, namun faktor-faktor yang melatarbelakangi stres kerja tersebut secara statistik terbukti tidak signifikan berhubungan, hanya variabel konflik interpersonal ( $p$ value $=0,003$ ), variasi kerja ( $p$ value $=0,002$ ) dan tanggung jawab terhadap pekerja lain ( $\mathrm{p}$ value 0,015 ) pada faktor pekerjaan yang memiliki hubungan dengan stres kerja. Peneliti menyarankan agar dilakukannya langkah pengendalian bagi perusahaan yaitu mendesain ulang alokasi pekerjaan untuk menyesuaikan kemampuan pekerja dengan variasi pekerjaan dan tanggung jawab kepada pihak lain. Selain itu, mendelegasikan tanggung jawab kepada pekerja lain yang memiliki variasi pekerjaan dan tanggung jawab yang lebih rendah dengan tetap menjadikan kapabilitas masing-masing pekerja sebagai referensi serta melakukan komunikasi yang efektif.
\end{abstract}

Kata Kunci: Stress kerja, Pekerja, Ad Medika

\section{PENDAHULUAN}

Centers for Disease Control and Prevention (CDC) menyebutkan terjadinya peningkatan jumlah kasus stres di dunia setiap tahunnya dari 4409 kasus pada tahun 1998 menjadi 5659 kasus pada tahun 2001. Setiap tahunnya industri di Amerika Serikat mengalami kerugian lebih dari US 300 miliar akibat stres kerja yang dialami para pekerjanya (AIS, 2013). Tiga dari empat orang di Amerika mengatakan bahwa pekerja pada saat ini memiliki tingkat stres kerja yang lebih tinggi dibandingkan dengan generasi beberapa tahun sebelumnya (NIOSH, 1999). Menurut Stranks (2005), stres kerja yang dialami pekerja tidak hanya merugikan bagi pekerja tetapi juga perusahaan. Dampak stres kerja yang dialami oleh pekerja dapat mempengaruhi performa dalam mencapai target perusahaan. Selain itu, menurut WHO, organisasi yang tidak sehat tidak akan mendapatkan usaha terbaik yang diberikan para pekerjanya. Hal ini tidak hanya berdampak pada performa organisasi tetapi juga keberlangsungan organisasi ke depannya. Berdasarkan data Direktur Jenderal Bina Upaya Kesehatan menyatakan bahwa dari jumlah populasi orang dewasa di Indonesia sebesar 150 juta jiwa sekitar 11,6 persen atau 17,4 juta jiwa mengalami gangguan mental emosional atau gangguan kesehatan jiwa berupa kecemasan dan depresi yang salah satu penyebabnya adalah stres kerja. AdMedika sebagai bagian dari Telkom Group juga menghadapi dinamika ekosistem bisnis dan perubahan organisasi sebagai peluang dan tantangan, di mana pekerja harus memiliki etos kerja yang tinggi dan sanggup menghadapi tuntutan dan tanggung jawab kerja, Hal ini dapat mengakibatkan stres kerja yang dapat merugikan pekerja dan karyawan. 
Dalam Direktorat Marketing dan Bisnis, terdapat 3 (tiga) divisi yaitu Divisi Marketing Enterprise Services, Divisi Marketing Business \& Government Services, dan Divisi Business Solution, Support, \& Service Delivery dimana terdapat total 84 (delapan puluh empat) pekerja. Penelitian dilakukan pada pekerja Divisi Business Solution, Support, \& Service Delivery sejumlah 31 (tiga puluh satu) pekerja karena divisi ini memiliki tanggung jawab yang lebih besar dibanding divisi lainnya.

Tanggung jawab dan etos kerja yang tinggi serta belum pernah dilakukan penelitian sebelumnya membuat Peneliti tertarik untuk melakukan penelitian tentang faktor-faktor yang berhubungan dengan stres kerja pada pekerja divisi business solution, support dan service delivery PT.Administrasi Medika Jakarta tahun 2017. Adapun tujuan umum dari penelitian adalah untuk mengetahui faktor-faktor yang berhubungan dengan stress kerja pada pekerja Divisi Business Solution, Support, \& Service Delivery di AdMedika Jakarta tahun 2017, sedangkan untuk tujuan khususnya yaitu:

1. Diketahuinya gambaran stress kerja pada pekerja Divisi Business Solution, Support, \& Service Delivery di AdMedika Jakarta tahun 2017.

2. Diketahuinya gambaran faktor individual (jenis kelamin, umur, status pernikahan, jumlah anak, dan masa kerja) pada pekerja Divisi Business Solution, Support, \& Service Delivery di AdMedika Jakarta tahun 2017.

3. Diketahuinya gambaran faktor pekerjaan (konflik peran, ketaksaan peran, konflik interpersonal, ketidakpastian pekerjaan, kurangnya kontrol, kurangnya kesempatan kerja, jumlah beban kerja, variasi beban kerja, tanggung jawab terhadap pekerja lain, kemampuan yang tidak digunakan, dan tuntutan mental) pada pekerja Divisi Business Solution, Support, \& Service Delivery di AdMedika Jakarta tahun 2017.

4. Diketahuinya gambaran aktivitas di luar pekerjaan pada pekerja Divisi Business Solution, Support, \& Service Delivery di AdMedika Jakarta tahun 2017.

5. Diketahuinya gambaran dukungan sosial pada pekerja Divisi Business Solution, Support, \& Service Delivery di AdMedika Jakarta tahun 2017.

6. Diketahuinya hubungan antara faktor individual (jenis kelamin, umur, status pernikahan, jumlah anak, dan masa kerja) dengan stress kerja pada pekerja Divisi Business Solution, Support, \& Service Delivery di AdMedika Jakarta tahun 2017.

7. Diketahuinya hubungan antara faktor pekerjaan (konflik peran, ketaksaan peran, konflik interpersonal, ketidakpastian pekerjaan,kurangnya kontrol, kurangnya kesempatan kerja, jumlah beban kerja, variasi beban kerja, tanggung jawab terhadap pekerja lain, kemampuan yang tidak digunakan, tuntutan mental dan waktu kerja) dengan stress kerja pada pekerja Divisi Business Solution, Support, \& Service Delivery di AdMedika Jakarta tahun 2017.

8. Diketahuinya hubungan antara aktivitas di luar pekerjaan dengan stress kerja pada pekerja Divisi Business Solution, Support, \& Service Delivery di AdMedika Jakarta tahun 2017.

9. Diketahuinya hubungan antara dukungan sosial dengan stress kerja pada pekerja Divisi Business Solution, Support, \& Service Delivery di AdMedika Jakarta tahun 2017.

Stres kerja dapat diartikan sebagai ketidaksesuaian antara permintaan dan tekanan tetapi dapat juga diartikan sebagai ketidaksesuaian dengan pengetahuan dan kemampuan. Situasi seperti ini tidak hanya berkaitan dengan 
kemampuan individu untuk menghadapi tekanan pekerjaan tetapi juga pengetahuan dan kemampuan individu yang tidak digunakan dengan baik sehingga memicu timbulnya masalah bagi diri mereka (WHO, 2003).

Menurut OSHA, individu akan merasakan stres ketika terjadi ketidakseimbangan antara permintaan dengan sumber daya yang dimilikinya. Secara umum, kondisi stres merupakan gangguan yang bersifat psikologis tetapi juga dapat berdampak pada fisiologi individu. Faktor yang dapat menyebabkan terjadinya stres kerja, antara lain kurangnya kontrol terhadap pekerjaan, ketidaksesuaian permintaan terhadap pekerja, dan kurangnya dukungan dari rekan kerja dan manajemen. Reaksi setiap individu dalam mengatasi stres berbeda-beda. Bagi beberapa individu merupakan sebuah hal yang mungkin untuk mengatasi permintaan pekerjaan yang tinggi tetapi hal ini belum tentu dapat terjadi pada individu lainnya sehingga kemampuan untuk menghadapi keadaan stres sangat tergantung pada evaluasi yang bersifat subjektif (OSHA, 2014). Faktor- faktor yang dapat mempengaruhi stress kerja menurut Caplan, et.al (1976) dan House (1974) dalam Quick, Murphy dan Hurrell (1992) antara lain: 1) Karakteristik Individu: jenis kelamin, umur, status pernikahan, jumlah anak dan masa kerja, 2) Karakteristik Pekerjaan: konflik peran, ketaksaan Peran, konflik interpersonal, ketidakpastian pekerjaan, kurangnya control, kurangnya kesempatan kerja, jumlah beban kerja, variasi beban kerja dan tanggungjawab terhadap pekerja lainnya, kemampuan yang tidak digunakan dan tuntutan mental, 3) Aktifitas di Luar Pekerjaan, dan Faktor Dukungan Sosial.

\section{METODE}

Metode penelitian yang digunakan adalah penelitian deskriptif analitik pendekatan cross sectional yaitu untuk melihat hubungan antara variabel independen dengan dependen. Penelitian ini dilakukan pada bulan April-Juni 2017 di Divisi Business Solution, Support dan Service Delivery AdMedika Jakarta tahun 2017. Pengumpulan data menggunakan kuesioner dengan sampel sebanyak 31 pekerja. Sampel dalam penelitian ini diambil dengan menggunakan teknik total sampling. Peneliti menggunakan kuesioner NIOSH Generic Job Stress Questionnaire. Hal ini dikarenakan kuesioner tersebut memiliki beberapa kelebihan dibandingkan dengan kuesioner lainnya terutama faktor sumber stres yang diukur lebih bersifat koomprehensif. Selain itu, kuesioner ini merupakan instrumen baku pengukuran stres kerja yang disahkan oleh NIOSH. Rehabilitas dan validitas kuesioner juga dapat dipercaya karena sudah diuji dan sering digunakan dalam penelitian. Analisa data yang digunakan dalam penelitian ini adalah analisa bivariat.

\section{HASIL DAN PEMBAHASAN}

\section{Analisa Univariat}

Hasil penelitian ini menunjukkan tingginya jumlah pekerja yang mengalami stres kerja pada pekerja Divisi Business Solution, Support, \& Service Delivery di AdMedika Jakarta tahun 2017 yaitu sebanyak 23 responden $(74,2 \%)$. Gambaran faktor individual adalah sebagai berikut, jumlah pekerja laki-laki sebanyak 22 responden (71\%). Jumlah pekerja dengan umur $\leq 34$ tahun yang menjadi responden, yaitu sebanyak. Jumlah pekerja dengan status menikah yaitu sebanyak 17 responden (54,8\%). Jumlah pekerja dengan jumlah anak $\leq 2$ sebanyak 30 responden (96,8\%). Jumlah pekerja dengan masa kerja $\leq 36$ bulan yaitu sebanyak 18 responden $(58,1 \%)$. Gambaran faktor pekerjaan adalah sebagai berikut, jumlah pekerja yang memiliki konflik peran sebanyak 23 responden $(72.1 \%)$. 


\section{Tabel 1}

Distribusi Frekuensi Stres Kerja, Faktor Individual, Faktor Pekerjaan,

Faktor Aktivitas di Luar Kantor dan Faktor Dukungan Sosial Pekerja di PT.Administrasi Admedika Jakarta Tahun 2017

\begin{tabular}{|c|c|c|c|}
\hline Variabel & Kategori & $\mathbf{N}$ & $\%$ \\
\hline \multicolumn{4}{|l|}{ Stres Kerja } \\
\hline \multirow{2}{*}{ Stres Kerja } & Stres & 23 & 74,2 \\
\hline & Tidak Stres & 8 & 25,8 \\
\hline \multicolumn{4}{|l|}{ Faktor Individual } \\
\hline \multirow{2}{*}{ Jenis Kelamin } & Laki-laki & 22 & 71 \\
\hline & Perempuan & 9 & 29 \\
\hline \multirow{2}{*}{ Umur } & $\leq 34$ tahun & 20 & 64,5 \\
\hline & $>34$ tahun & 11 & 35,5 \\
\hline \multirow{2}{*}{ Status Pernikahan } & Menikah & 17 & 54,8 \\
\hline & Tidak menikah & 14 & 45,2 \\
\hline \multirow{2}{*}{ Jumlah Anak } & $>2$ anak & 1 & 3,2 \\
\hline & $\leq 2$ anak & 30 & 96,8 \\
\hline \multirow{2}{*}{ Masa Kerja } & $>36$ bulan & 13 & 41,9 \\
\hline & $\leq 36$ bulan & 18 & 58,1 \\
\hline \multicolumn{4}{|l|}{ Faktor Pekerjaan } \\
\hline \multirow{2}{*}{ Konflik Peran } & Ada & 23 & 74,2 \\
\hline & Tidak ada & 8 & 25,8 \\
\hline \multirow{2}{*}{ Ketaksaan Peran } & Ada & 4 & 12,5 \\
\hline & Tidak ada & 27 & 87,1 \\
\hline \multirow{2}{*}{ Konflik Interpersonal } & Ada & 14 & 45,2 \\
\hline & Tidak ada & 17 & 54,8 \\
\hline \multirow{2}{*}{ Ketidakpastian Pekerjaan } & Ada & 15 & 48,4 \\
\hline & Tidak ada & 16 & 51,6 \\
\hline \multirow{2}{*}{ Kurangnya Kontrol } & Kurang kontrol & 23 & 74,2 \\
\hline & Memiliki control & 8 & 25,8 \\
\hline \multirow{2}{*}{ Kesempatan Kerja } & Rendah & 24 & 77,4 \\
\hline & Tinggi & 7 & 22,6 \\
\hline \multirow{2}{*}{ Beban Kerja } & Tinggi & 30 & 96,8 \\
\hline & Cukup & 1 & 3,2 \\
\hline \multirow{2}{*}{$\begin{array}{l}\text { Tanggung Jawab Terhadap } \\
\text { Pekerja Lain }\end{array}$} & Tinggi & 16 & 51,6 \\
\hline & Rendah & 15 & 48,4 \\
\hline \multirow{2}{*}{$\begin{array}{l}\text { Kemampuan Yang Tidak } \\
\text { Digunakan }\end{array}$} & $\begin{array}{l}\text { Tidak } \\
\text { menggunakan }\end{array}$ & 11 & 35,5 \\
\hline & Menggunakan & 20 & 64,5 \\
\hline \multirow{2}{*}{ Tuntutan Mental } & Tinggi & 23 & 74,2 \\
\hline & Rendah & 8 & 25,8 \\
\hline \multicolumn{4}{|c|}{ Faktor Aktivitas Diluar Kantor } \\
\hline \multirow{2}{*}{ Aktivitas di Luar Kantor } & $>2$ & 10 & 32,3 \\
\hline & $\leq 2$ & 21 & 67,7 \\
\hline \multicolumn{4}{|l|}{ Faktor Dukungan Sosial } \\
\hline \multirow{2}{*}{ Dukungan Sosial } & Rendah & 12 & 38,7 \\
\hline & Tinggi & 19 & 61,3 \\
\hline
\end{tabular}

Sumber: Hasil Analisa SPSS 19

Jumlah pekerja yang memiliki ketaksaan peran sebanyak 27 responden $(87,1 \%)$. Jumlah pekerja yang tidak memiliki ketidakpastian pekerjaan sebanyak 16 responden (51,6\%). Jumlah pekerja dengan kurangnya kontrol sebanyak 23 responden $(74,2 \%)$. Jumlah pekerja dengan kesempatan kerja rendah sebanyak 24 responden $(77,4 \%)$. Jumlah pekerja dengan beban kerja tinggi sebanyak 30 responden $(96,8 \%)$. Jumlah pekerja dengan variasi kerja tinggi sebanyak 25 responden $(80,6 \%)$. Jumlah pekerja dengan memiliki tanggung jawab tinggi 
sebanyak 16 responden $(51,6 \%)$. Jumlah pekerja dengan memiliki kemampuan yang digunakan sebanyak 20 responden (64,5\%). Jumlah pekerja dengan memiliki tuntutan mental tinggi sebanyak 23 responden (74,2\%).

Gambaran faktor aktivitas diluar kantor yaitu pekerja dengan memiliki $\leq 2$ aktivitas di luar kantor sebanyak 21 responden $(67,7 \%)$, dan untuk faktor dukungan sosial yaitu pekerja dengan memiliki dukungan sosial tinggi sebanyak 19 responden $(61,3 \%)$.

\section{Analisa Bivariat}

Hasil analisis hubungan antara faktor individual dan stres kerja adalah sebagai berikut, variabel jenis kelamin memiliki nilai $p$-value 1,000 ( $p$-value > 0,05), dapat disimpulkan tidak ada hubungan antara jenis kelamin dan stres kerja. Hasil penelitian tersebut berbeda dengan penelitian yang dilakukan di Swedia menunjukkan bahwa pada pekerja perempuan tingkat keparahan gejala stres yang muncul cenderung lebih tinggi dibandingkan pekerja laki- laki. Tingkat gejala stres ini dipengaruhi oleh permasalahan pekerjaan dan keluarga yang mereka hadapi (Krantz, Burntson, \& Lundberg, 2005).

Hubungan variabel konflik interpersonal dengan stres kerja diperoleh nilai $p$-value 1,000 ( $p$-value > 0,05), dapat disimpulkan tidak ada hubungan antara konflik interpersonal dan stres kerja. Hasil penelitian tersebut berbeda dengan penelitian yang dilakukan pada karyawan bank di Semarang dimana ditemukan bahwa pada umur yang lebih tua maka pekerja akan memiliki pengalaman yang lebih banyak dibandingkan pekerja yang berumur muda sehingga tingkat stres akan lebih rendah. Pada penelitian tersebut umur yang lebih tua berada pada kategori 34 tahun ke atas (Fitri, 2013).

Hubungan variabel status pernikahan dengan stres kerja diperoleh nilai $p$-value 0,097 ( $p$-value > 0,05), dapat disimpulkan tidak ada hubungan antara status pernikahan dan stres kerja.

Hasil ini berbeda dengan hasil penelitian yang dilakukan terhadap pekerja kesehatan dimana terdapat hubungan antara status pernikahan dengan stres kerja, dimana pekerja yang telah menikah cenderung mengalami stres yang lebih rendah Karena mendapat dukungan dari pasangannya (Olatunji \& Mokuolu, 2014).

Hubungan variabel jumlah anak dengan stres kerja diperoleh nilai p-value 1,000 ( $p$-value $>0,05)$, dapat disimpulkan tidak ada hubungan antara jumlah anak dan stres kerja. Hasil ini berbeda dengan hasil penelitian Twenge et al (2015) yang menunjukkan bahwa orang tua yang memiliki anak lebih dari dua akan memiliki tingkat kepuasan pernikahan yang rendah serta tingginya stres (Hess, 2008).

Hubungan variabel masa kerja dengan stres kerja diperoleh nilai p-value 1,000 ( $p$-value $>0,05$ ), dapat disimpulkan tidak ada hubungan antara masa kerja dan stres kerja. Hasil ini berbeda dengan hasil penelitian Frone (1998) dimana semakin lama masa kerja cenderung memiliki pengalaman yang lebih baik dan tanggung jawab pekerjaan yang lebih besar (Barling et al, 2005).

Hasil analisis hubungan antara faktor pekerjaan dan stres kerja adalah sebagai berikut, variabel konflik peran memiliki nilai $p$-value 0, 393 ( -value > 0,05), dapat disimpulkan tidak ada hubungan antara konflik peran dan stres kerja. Hasil ini berbeda dengan hasil penelitian yang dilakukan pada manajer di Singapura menunjukkan bahwa secara signifikan konflik peran berhubungan dengan munculnya stres kerja (Quah \& Campbell, 1994). 


\section{Tabel 2}

Hubungan Antara Faktor Individual, Faktor Pekerjaan,

Faktor Aktivitas di Luar Kantor dan Faktor Dukungan Sosial Pekerja Dengan Stres Kerja di PT.Administrasi Admedika Jakarta Tahun 2017

\begin{tabular}{|c|c|c|c|c|c|c|c|}
\hline \multirow{2}{*}{ Variabel } & \multirow[b]{2}{*}{ Kategori } & \multicolumn{2}{|c|}{ Stres Kerja } & \multirow[b]{2}{*}{$P$ Value } & \multirow[b]{2}{*}{$95 \mathrm{CI}$} & & \multirow[b]{2}{*}{ OR } \\
\hline & & Stress & $\begin{array}{c}\text { Tidak } \\
\text { Stress }\end{array}$ & & & & \\
\hline \multicolumn{8}{|c|}{ Faktor Individual } \\
\hline \multirow{2}{*}{ Jenis Kelamin } & Laki-laki & $\begin{array}{c}16 \\
(72,7 \%)\end{array}$ & $\begin{array}{c}6 \\
(27,3 \%)\end{array}$ & \multirow[t]{2}{*}{1,000} & \multirow{2}{*}{$\begin{array}{l}0,122 \\
4,751\end{array}$} & \multirow[t]{2}{*}{-} & \multirow{2}{*}{0,762} \\
\hline & Perempuan & $\begin{array}{c}7 \\
(77,8 \%) \\
\end{array}$ & $\begin{array}{c}2 \\
(22,2 \%)\end{array}$ & & & & \\
\hline \multirow{2}{*}{ Umur } & $\leq 34$ tahun & $\begin{array}{c}15 \\
(75,0 \%)\end{array}$ & $\begin{array}{c}5 \\
(25,0 \%)\end{array}$ & \multirow{2}{*}{1,000} & \multirow{2}{*}{$\begin{array}{l}0,122 \\
5,969\end{array}$} & \multirow{2}{*}{-} & \multirow{2}{*}{1,125} \\
\hline & $>34$ tahun & $\begin{array}{c}18 \\
(72,7 \%)\end{array}$ & $\begin{array}{c}3 \\
(27,3 \%)\end{array}$ & & & & \\
\hline \multirow{2}{*}{$\begin{array}{l}\text { Status } \\
\text { Pernikahan }\end{array}$} & Menikah & $\begin{array}{c}15 \\
(88.2 \%)\end{array}$ & $\begin{array}{c}2 \\
(11,8)\end{array}$ & \multirow{2}{*}{0,097} & \multirow{2}{*}{$\begin{array}{l}0.915 \\
34,572\end{array}$} & \multirow[t]{2}{*}{-} & \multirow{2}{*}{5,625} \\
\hline & Tidak menikah & $\begin{array}{c}8 \\
(57,1 \%)\end{array}$ & $\begin{array}{c}6 \\
(42,9 \%) \\
\end{array}$ & & & & \\
\hline \multirow{2}{*}{ Jumlah Anak } & $>2$ anak & $\begin{array}{c}1 \\
(100 \%) \\
\end{array}$ & $\begin{array}{c}0 \\
(0,0 \%) \\
\end{array}$ & \multirow{2}{*}{1,000} & \multirow{2}{*}{$\begin{array}{l}1,099 \\
1,692\end{array}$} & \multirow[t]{2}{*}{-} & \multirow{2}{*}{1,364} \\
\hline & $\leq 2$ anak & $\begin{array}{c}22 \\
(73,3 \%)\end{array}$ & $\begin{array}{c}8 \\
(26,7 \%)\end{array}$ & & & & \\
\hline \multirow{2}{*}{ Masa Kerja } & $>36$ bulan & $\begin{array}{c}12 \\
(92,3 \%) \\
\end{array}$ & $\begin{array}{c}1 \\
(7,7 \%) \\
\end{array}$ & \multirow{2}{*}{0.095} & \multirow{2}{*}{$\begin{array}{l}0,805 \\
72,405\end{array}$} & \multirow[t]{2}{*}{-} & 7,636 \\
\hline & $\leq 36$ bulan & $\begin{array}{c}11 \\
(61,1 \%)\end{array}$ & $\begin{array}{c}7 \\
(38,9 \%) \\
\end{array}$ & & & & 1,050 \\
\hline Faktor Pekerjaa & & & & & & & \\
\hline Konflit Doran & Ada & $\begin{array}{c}18 \\
(78,3 \%)\end{array}$ & $\begin{array}{c}5 \\
(21,7 \%)\end{array}$ & 0303 & 0,379 & - & 160 \\
\hline Kontl1k Peran & Tidak ada & $\begin{array}{c}5 \\
(62,5 \%)\end{array}$ & $\begin{array}{c}3 \\
(37,5 \%)\end{array}$ & 0,393 & 12,316 & & 2,100 \\
\hline Ketakcan Peran & Ada & $\begin{array}{c}4 \\
(100 \%) \\
\end{array}$ & $\begin{array}{c}0 \\
(0,0 \%)\end{array}$ & 0550 & 1,113 & - & 1421 \\
\hline Ketaksaan peran & Tidak ada & $\begin{array}{c}19 \\
(70,4 \%)\end{array}$ & $\begin{array}{c}8 \\
(29,6 \%)\end{array}$ & 0,550 & 1,815 & & 1,421 \\
\hline Konflik & Ada & $\begin{array}{c}14 \\
(100 \%) \\
\end{array}$ & $\begin{array}{c}0 \\
(0,0 \%) \\
\end{array}$ & 0003 & 1,207 & - & 1880 \\
\hline Interpersonal & Tidak ada & $\begin{array}{c}9 \\
(52,9 \%) \\
\end{array}$ & $\begin{array}{c}8 \\
(47,1 \%) \\
\end{array}$ & 0,003 & 2,957 & & 1,009 \\
\hline Ketidakpastian & Ada & $\begin{array}{c}11 \\
(73,3 \%)\end{array}$ & $\begin{array}{c}4 \\
(26,7 \%) \\
\end{array}$ & 1000 & 0,183 & - & 0.017 \\
\hline Pekerjaan & Tidak ada & $\begin{array}{c}12 \\
(75,0 \%)\end{array}$ & $\begin{array}{c}4 \\
(25,0 \%)\end{array}$ & 1,000 & 4,583 & & 0,911 \\
\hline & Kurang control & $\begin{array}{c}18 \\
(78,3 \%)\end{array}$ & $\begin{array}{c}5 \\
(21,7 \%) \\
\end{array}$ & & & & \\
\hline $\begin{array}{l}\text { Kurangnya } \\
\text { Kontrol }\end{array}$ & Memiliki control & $\begin{array}{c}5 \\
(62,5 \%)\end{array}$ & $\begin{array}{c}3 \\
(37,5 \%)\end{array}$ & 0,393 & $\begin{array}{l}0,379 \\
12,316\end{array}$ & - & 2,160 \\
\hline Kesempatan & Rendah & $\begin{array}{c}18 \\
(75,0 \%)\end{array}$ & $\begin{array}{c}6 \\
(25,0 \%)\end{array}$ & 1000 & 0,183 & - & 1200 \\
\hline Kerja & Tinggi & $\begin{array}{c}5 \\
(71,4 \%)\end{array}$ & $\begin{array}{c}2 \\
(28,6 \%)\end{array}$ & 1,000 & 7,882 & & 1,200 \\
\hline & & 23 & 7 & & & & \\
\hline & Tinggi & $(76,7 \%)$ & $(23,3 \%)$ & 0,258 & & & \\
\hline
\end{tabular}




\begin{tabular}{|c|c|c|c|c|c|c|c|}
\hline \multirow{3}{*}{$\begin{array}{r}\text { Variabel } \\
\text { Beban Kerja }\end{array}$} & \multirow{3}{*}{$\begin{array}{l}\text { Kategori } \\
\text { Cukup }\end{array}$} & \multicolumn{2}{|c|}{ Stres Kerja } & \multirow{3}{*}{ P Value } & \multirow{2}{*}{\multicolumn{2}{|c|}{95 CI }} & \multirow[b]{2}{*}{ OR } \\
\hline & & \multirow{2}{*}{$\begin{array}{c}\text { Stress } \\
0 \\
(0,0 \%)\end{array}$} & \multirow{2}{*}{$\begin{array}{c}\begin{array}{c}\text { Tidak } \\
\text { Stress }\end{array} \\
1 \\
(1005)\end{array}$} & & & & \\
\hline & & & & & $\begin{array}{l}0,122 \\
0,446\end{array}$ & - & 0,233 \\
\hline \multirow{2}{*}{ Variasi Kerja } & Tinggi & $\begin{array}{c}22 \\
(88,0 \%)\end{array}$ & $\begin{array}{c}3 \\
(12,0 \%)\end{array}$ & \multirow{2}{*}{0,002} & \multirow{2}{*}{\multicolumn{2}{|c|}{$\begin{array}{l}3,124- \\
430,33\end{array}$}} & \multirow{2}{*}{36,667} \\
\hline & Cukup & $\begin{array}{c}1 \\
(16,7 \%)\end{array}$ & $\begin{array}{c}5 \\
(83,3 \%)\end{array}$ & & & & \\
\hline \multirow{2}{*}{$\begin{array}{l}\text { Tanggung Jawab } \\
\text { Terhadap } \\
\text { Pekerja Lain }\end{array}$} & Tinggi & $\begin{array}{c}15 \\
(93,8 \%) \\
\end{array}$ & $\begin{array}{c}1 \\
(6,3 \%) \\
\end{array}$ & \multirow{2}{*}{0,015} & \multirow{2}{*}{$\begin{array}{l}1,364 \\
126,305\end{array}$} & \multirow{2}{*}{-} & \multirow{2}{*}{13,125} \\
\hline & Rendah & $\begin{array}{c}8 \\
(53,3 \%) \\
\end{array}$ & $\begin{array}{c}7 \\
(46,7 \%)\end{array}$ & & & & \\
\hline \multirow{2}{*}{$\begin{array}{l}\text { Kemampuan } \\
\text { Yang Tidak } \\
\text { Digunakan }\end{array}$} & $\begin{array}{l}\text { Tidak } \\
\text { Menggunakan }\end{array}$ & $\begin{array}{c}8 \\
(72,7 \%)\end{array}$ & $\begin{array}{c}3 \\
(27,3 \%)\end{array}$ & \multirow{2}{*}{1,000} & \multirow{2}{*}{$\begin{array}{l}0,168 \\
4,716\end{array}$} & \multirow{2}{*}{-} & \multirow{2}{*}{0,889} \\
\hline & Menggunakan & $\begin{array}{c}15 \\
(75,0 \%)\end{array}$ & $\begin{array}{c}5 \\
(25,0 \%)\end{array}$ & & & & \\
\hline \multirow[b]{2}{*}{ Tuntutan Mental } & Tinggi & $\begin{array}{c}18 \\
(78,3 \%)\end{array}$ & $\begin{array}{c}5 \\
(21,7 \%)\end{array}$ & \multirow[b]{2}{*}{0,393} & \multirow[b]{2}{*}{$\begin{array}{l}0,379 \\
12,316\end{array}$} & \multirow{2}{*}{-} & \multirow[b]{2}{*}{2,160} \\
\hline & Rendah & $\begin{array}{c}5 \\
(62,5 \%)\end{array}$ & $\begin{array}{c}3 \\
(37,5 \%)\end{array}$ & & & & \\
\hline \multicolumn{8}{|c|}{ Faktor Aktivitas Diluar Kantor } \\
\hline \multirow{2}{*}{$\begin{array}{l}\text { Aktivitas di Luar } \\
\text { Kantor }\end{array}$} & $>2$ & $\begin{array}{c}9 \\
(90,0 \%)\end{array}$ & $\begin{array}{c}1 \\
(10,0 \%)\end{array}$ & \multirow{2}{*}{0,222} & \multirow{2}{*}{$\begin{array}{l}0,471 \\
42,970\end{array}$} & \multirow[t]{2}{*}{-} & \multirow{2}{*}{4,500} \\
\hline & $=<2$ & $\begin{array}{c}14 \\
(66,7 \%)\end{array}$ & $\begin{array}{c}7 \\
(33,3 \%)\end{array}$ & & & & \\
\hline \multicolumn{8}{|c|}{ Faktor Dukungan Sosial } \\
\hline \multirow{2}{*}{ Dukungan Sosial } & Rendah & $\begin{array}{c}11 \\
(91,7 \%)\end{array}$ & $\begin{array}{c}1 \\
(8,3 \%)\end{array}$ & \multirow{2}{*}{0,108} & \multirow{2}{*}{$\begin{array}{l}0,667 \\
60,840\end{array}$} & - & \\
\hline & Tinggi & $\begin{array}{c}12 \\
(63,2 \%)\end{array}$ & $\begin{array}{c}7 \\
(36,8)\end{array}$ & & & & 6,417 \\
\hline
\end{tabular}

Sumber: Hasil Analisa SPSS 19

Hubungan variabel ketaksaan peran dengan stres kerja diperoleh nilai p-value 0,550 ( $p$-value $>0,05)$, dapat disimpulkan tidak ada hubungan antara ketaksaan peran dan stres kerja.Hasil ini sesuai dengan penelitian Lord (1996) Narayanan et al (1999), tidak ditemukan hubungan antara ketaksaan peran dengan stres kerja pada pekerja klerikal, polisi, dan professor (Sams, 2005).Hubungan variabel konflik interpersonal dengan stres kerja diperoleh nilai $p$-value 0,003 ( $p$-value $>0,05$ ), dapat disimpulkan terdapat hubungan antara konflik interpersonal dan stres kerja. Hasil ini sesuai dengan hasil penelitian yang dilakukan pada pekerja di Jepang menunjukkan bahwa pada pekerja baik laki-laki maupun perempuan konflik interpersonal berpengaruh terhadap stres secara psikologis (Tsuno et al., 2009).

Hubungan variabel ketidakpastian pekerjaan dengan stres kerja diperoleh nilai $p$-value 0,003 ( $p$-value >0,05), dapat disimpulkan tidak ada hubungan antara ketidakpastian pekerjaan dan stres kerja. Hasil ini sesuai dengan hasil penelitian yang dilakukan terhadap pekerja di beberapa negara seperti Amerika, Jerman, Hungaria, Jepang, Slovenia, Korea, Taiwan, dan Inggris karena perbedaan karakteristik di setiap negara (Perrewe \& Gnster, 2011). Hubungan variabel kurangnya kontrol dengan stres kerja diperoleh nilai $p$-value 0,393 ( $p$-value > 0,05), dapat disimpulkan tidak ada hubungan antara kurangnya kontrol dan stres kerja. Hasil ini berbeda dengan hasil penelitian yang dilakukan oleh Marmot et al (1997) menunjukkan bahwa pekerja yang memiliki kemampuan kontrol kerja lebih sedikit memiliki risiko empat kali lebih besar terkena serangan jantung dibandingkan dengan pekerja yang memiliki kontrol lebih besar terhadap pekerjaannya. 
Hubungan variabel kesempatan kerja dengan stres kerja diperoleh nilai $p$-value 1,000 ( $p$-value $>0,05$ ), dapat disimpulkan tidak ada hubungan antara kesempatan kerja dan stres kerja. Hasil ini berbeda dengan hasil penelitian yang dilakukan oleh Cobb dan Kasl (1977) yang menunjukkan bahwa meskipun pekerja telah berusaha mengantisipasi kemungkinan sulitnya mendapatkan pekerjaan lagi, namun hal tersebut tetap dapat meningkatkan kemungkinan terjadinya depresi dan perasaan gelisah (L. B. Singh, 2006).

Hubungan variabel beban kerja dengan stres kerja diperoleh nilai $p$-value 0,258 ( $p$-value >0,05),dapat disimpulkan tidak ada hubungan antara beban kerja dan stres kerja. Hasil ini berbeda dengan hasil penelitian yang dilakukan pada pekerja di Jepang, dimana menunjukkan bahwa jumlah beban kerja secara signifikan berkaitan dengan munculnya sejumlah gejala stres, seperti mudah marah, kelelahan, gelisah, dan gejala depresi (Nishitani, Sakakibara, \& Akiyama, 2013).

Hubungan variabel variasi kerja dengan stres kerja diperoleh nilai $p$-value 0,002 ( $p$-value $>0,05$ ), dapat disimpulkan terdapat hubungan antara variasi kerja dan stres kerja. Hasil ini sesuai dengan hasil penelitian yang dilakukan pada petugas pemadam kebakaran menunjukkan bahwa variasi beban kerja yang tinggi berhubungan secara signifikan terhadap munculnya gejala stres berupa insomnia (Afrianti, Widyahening, Amri, \& Kusumawardhani, 2011).

Hubungan variabel tanggungjawab terhadap pekerja lain dengan stres kerja diperoleh nilai $p$-value 0,015 ( $p$ value $>0,05$ ), dapat disimpulkan terdapat hubungan antara tanggungjawab terhadap pekerja lain dan stres kerja. Hasil ini sesuai dengan penelitian Sulsky \& Smith (2005) menunjukkan bahwa seorang pekerja yang memiliki tanggung jawab dalam mengatur orang lain akan mengalami tingkat stres yang cukup tinggi.

Hubungan variabel kemampuan yang tidak digunakan dengan stres kerja diperoleh nilai $p$-value 1,000 ( $p$-value $>0,05)$, dapat disimpulkan tidak ada hubungan antara kemampuan yang tidak digunakan dan stres kerja. Hasil ini berbeda dengan hasil penelitian yang dilakukan pada pekerja di Jepang didapatkan hasil bahwa kemampuan pekerja yang tidak digunakan dengan baik dapat meningkatkan risiko stres kerja yang berdampak pada peningkatan kadar tekanan darah (Konno \& Munakata, 2014).

Hubungan variabel tuntutan mental dengan stres kerja diperoleh nilai $p$-value 0,393 ( $p$-value $>0,05$ ), dapat disimpulkan tidak ada hubungan antara tuntutan mental dan stres kerja. Hal ini dapat terjadi karena pekerja sudah merasa terbiasa dengan tekanan pekerjaan yang dirasakan sehingga tidak menganggap tuntutan mental sebagai penyabab stres.

\section{KESIMPULAN DAN REKOMENDASI}

Berdasarkan hasil penelitian mengenai faktor-faktor yang yang berhubungan dengan stress kerja pada pekerja Divisi Business Solution, Support, \& Service Delivery di AdMedika Jakarta tahun 2017, dapat disimpulkan bahwa: Jumlah pekerja yang mengalami stres kerja pada penelitian ini lebih banyak dibanding pekerja yang tidak mengalami stres kerja, yaitu sebanyak 23 responden $(74,2 \%)$ dari 31 responden. Meskipun jumlah stres kerja relatif cukup tinggi, namun faktor-faktor yang melatarbelakangi stres kerja tersebut secara statistik terbukti tidak signifikan berhubungan, hanya variabel konflik interpersonal, variasi kerja dan, tanggung jawab terhadap pekerja lain pada faktor pekerjaan yang memiliki hubungan dengan stres kerja. Peneliti merekomendasikan PT.Administrasi Jakarta untuk mengambil langkah pengendalian antara lain: 1) Mendesain ulang alokasi 
pekerjaan untuk menyesuaikan kemampuan pekerja dengan variasi pekerjaan dan tanggung jawab kepada pihak lain, 2) Mendegelasikan tanggung jawab kepada pekerja lain yang memiliki variasi pekerjaan dan tanggung jawab yang lebih rendah dengan tetap menjadikan kapabilitas masing-masing pekerja sebagai referensi, 3) Melakukan komunikasi yang efektif secara rutin baik secara formal seperti dalam pertemuan mingguan maupun secara informal seperti pendekatan pribadi untuk mendiskusikan permasalahan yang terjadi beserta jalan keluarnya, 4) Mengadakan secara rutin agenda atau acara untuk menghibur karyawan, seperti gathering, lomba, kuis, dll, dan 5) Menyediakan fasilitas hiburan, olah raga, ataupun Kesenian yang dapat menjadi penyaluran hobi sehingga dapat mengurangi tingkat stres pekerja. Sedangkan untuk para pekerja diharapkan dapat melakukan manajemen stres dengan berpikir positif terhadap sumber stres yang dirasakan, menyampaikan masukan dan saran mengenai keluhan stres kerja kepada atasan dan rekan kerja serta mencari aktifitas atau kegiatan sebagai hiburan dan dapat menghilangkan stres. Begitu juga untuk peneliti selanjutnya diharapkan dapat meningkatkan jumlah sampel, melakukan perhitungan untuk seluruh variabel pada NIOSH Generic Job Stress Questionnaire, dan melakukan penelitian stres kerja hingga ke tahap stres kerja akut dan kronis.

\section{REFERENSI}

1. Afrianti, R., Widyahening, I. S., Amri, Z., \& Kusumawardhani, A.,2011. Stressor Kerja dan Insomia pada Petugas Pemadam Kebakaran di Jakarta Selatan. Journal Indonesia Medical Association, no 21, hh 61 AIS.,2013. Workplace Stress. www.stress.org/workplace-stress/.

2. Aldwin, Y., 2012. Pengolahan dan Analisa Data Statistik di Bidang Kesehatan. Jakarta: Fakultas Kedokteran dan Ilmu Kesehatan UIN Syatif Hidayatullah Jakarta.

3. Anismasahun, \& Oladeni, 2012. Effects of Length of Marriage and Number of Children on Martial Satisfaction among Baptist Couple in Lagos State, Nigeria. International Journal of Current Research, Vol 4, hh 163-171.

4. Antoniou, Polychroni, F., \& Vlachakis, A. N., 2006. Gender and Age Differences in Occupational Stress and Professional Burnout Between Primary and High school Teacher in Greece. Journal of Magerial Psychology, 81, 682-890.

5. Barling, J., Kelloway, E. K., \& Frone, M. R., 2005. Handbook of Work Stres. United States of America: Sage Publication Inc.

6. Bickford, M., 2005. Stress in Workplace: a General Overview of the Cause, the Effects, and the Solution, www.cmhanl.ca/pdf/Work\%place\%20Stress.pdf

7. Bizymoms, 2013. The Lack of Job Opportunities. www.bizymoms.com/job-career/lack-of-jobopportunities.html.

8. Burgard, S. A., Kalousova, L., \& Seefeldt, K. S., 2012. Perceived Job Insecurity and Health: The Michigan Recession and Recovery Study. Journal of Occupational and Environmental Medicine, 54(9), 1101-1106.

9. Cardwell, M., \& Flannagan, C., 2005. Psychology AS.

10. CDC, 2004. Worker Health Chartbook. Columbia: Deparatment of Health and Human Services. 
11. CMHA, 2014. Children and the Stress of Parenting. www.cmha.ca/mental_health/the-stress-ofparenting/\#.U15CD_mSxnY.

12. Cooper, C. L., 2013. From Stress to Wellbeing. New York: Palgrave Macmillan.

13. Desy. 2002. Tingkat Stres Kerja dan Faktor-faktor yang Berhubungan dengan Stres Kerja pada Karyawan Bagian Marketing Services PT Unilever Indonesia Tbk Jakarta Tahun 2002. Universitas Indonesia, Depok.

14. Dollard, M. F., Winefield, A. H., \& Winefield, H. R., 2003. Occupational Stress in Service Professions. New York: Taylor \& Francis Ltd.

15. Fink, G., 2010. Stress Consequences: Mental, Neuropsychological, and Socioeconomic. United Kingdom: Elsevier

16. Fitri, A. M., 2013. Analisis Faktor-faktor yang Berhubungan Dengan Kejadian Stress Kerja Pada Karyawan Bank. Jurnal Kesehatan Masyarakat, 2.

17. Flin, R. H., O’Connor, P., \& Crichton, M., 2008. Safety at the Sharp End: a Guide to Non-technical Skills. United States of America: Ashgate Publishing Limited.

18. Forbes., 2012. The Key of Economic Growth: Reduce of the Unemployment Rate. www.forbes.com/sites/mikepatton/2012/08/27/the-key-to-economic-growth-reduce-the-unemploymentrate/

19. Gatchel, R. J., \& Schultz, I. Z., 2012. Handbook of Occupational Health and Wellness. New York: Springer.

20. Halkos, G., \& Bousinakis, D., 2010 The Effect of Stress and Satisfaction on Productivity. International Journal of Productivity and Performance Management, 59(5), 415-431.

21. Hess, J., 2008. Martial Satisfaction and Parental Stress. (Magister), Utah State University, Logan, Utah. Retrieved from http://books/google.co.id/books?id=taT34ocDf8C \&printsec=frontcover\&hl=id\# $\mathrm{v}=$ onepage $\& \mathrm{q} \& \mathrm{f}=$ false

22. Hidayat, B. U. A., 2012. Hubungan Tingkat Stress dengan Tingkat Insomnia pada Mahasiswa Program Studi Ilmu Keperawatan Universitas Diponogoro, Semarang. Retrieved from www.eprints.undip.ac.id/33160/10/Artikel_HUBUNGAN_TINGKAT_STRES_DENGAN_DENGAN_ KEJADIAN_INSOMNIA.pdf.

23. Hiriyappa, B., 2013. A Person Who Can Manage the Stress at Workplace in a Organization.

24. ILO, 2003. Work Stress in The Context of Transition. Budapest: ILO.

25. Ikeda, Nakata, Takahashi, Hojou, Haratani, Nishikido, \& Kamibeppu, 2009. Correlates of Depressive Symptoms among Workers in Small and Medium Scale Manufacturing Enterprise in Japan. Occupational Health, 51, 26-37.

26. Jamal, M., \& Ahmed, S. W., 2009. Job Stress, Stress-Prone Type a Behavior, and Personal and Organizational Consequences. Canadian Journal of Administrative Science, 2(2), 360-374.

27. Jex, S. M., \& Britt, T. M. W., 2008. Organizational Psychology: a Scientist Practitioner Approach. Canada: John Wiley \& Sons Inc.

28. Juneja, N., 2004. How Principals Manage Stress: Strategis for Successful Coping. India: Krishan Mittal. 
29. Konno, \& Munakata, 2014. Skill Underutilization is Associated with Higher Prevalence of Hypertension the Watari Study. Occupational Health.

30. Koradecka, D, 2010. Handbook of Occupational and Health. United States of America: CRC Press.

31. Krantz, G., Burntso, L., \& Lundberg, U., 2005. Total Workload, Work Stress and Perceived Symptoms in Swedish Male and Female White-collar Employees. European Journal of Public Health, 15, 209-214.

32. Mroczek, D. K., \& Almeida, D., 2004. The Effect of Daily Stress, Personality, and Age on Daily Negative Effect. Journal of Personality.

33. NIOSH, 1999a. Stress at Work. What Can be Done About Job Stress? www.cdc.gov/niosh/docs/99101/pdfs/99-101.pdf.

34. Nishitani, N., Sakakibara, H., \& Akiyama, I., 2013. Short Sleeping Time and Job Stress in Japanese White-Collar Workers. The Open Sleep Journal, 6, 104-109.

35. Notoatmodjo, S., 2010. Metodologi Penelitian Kesehatan. Jakarta: Rineka Cipta.

36. O’Rourke, J., \& Collins, S. ,2009. Managing Conflict and Workplace Relationship.

37. Ogden, J., 2012. Health Psychology. New York: McGraw Hill.

38. Olatunji, \& Mokuolu, B., 2014. The Influence of Sex, Marital Status, and Tenure of Service on Job Stress, and Job Satisfaction of Health Workers in Nigerian Federal Health Institution. International Multidisciplinary Journal, 8(1), 126-133.

39. Olpin, M., \& Hesson, M., 2010. Stress Management for Life. United States of America: Wadsworth Cengange Learning.

40. OSHA, 2014. Stress - Definition and Symptoms www. osha.europa.eu/en/themes/psychosocial-risksand-stress.

41. Oxington, K. H., 2005. Psychology of Stress. New York: Nova Science Publishers.

42. Perrewe, P. L., \& Ganster, D. C., 2011. The Role of Individual Differences in Occupational Stress and Well Being. United Kingdom: Emerald Group Publishing Limited.

43. Praag, H. V., Kloet, E. D., OS, J. V., 2004. Stress, the Brain Depression. New York: Cambridge University Press.

44. Ram,N., Khoso, I., Shah, A. A., Chandio, F. R., \& Shaikih, F. M., 2011. Role Conflict and Ambiguity as Factors in Work Stress among Managers: a Case Study of Manufacturing Sector in Pakistan. Asian Social Science, 7(2).

45. Robbins, S. P., 2009. Organizational Behavior in Southern Africa. South Africa: Pearson Education.

46. Sams, D., 2005. An Empirical Examination of Job Stress and Management of Emotionally-based Behavior: Frontline Social Service Personnel Perspective. University of South Florida, United States of America. Retrieved from WwW. books.google.co.id/books?id=_5qVD8WjLvkC\&pg=PA35\&dq=role+conflict+to+job+stress\&hl=id\&sa $=\mathrm{X} \& \mathrm{ei}=-$

XKiU_XPPMmfugSL6YHYCg\&ved=0CDIQ6AEwAw\#v=onepage $\& q=$ role $\% 20$ conflict $\% 20$ to $\% 20$ job $\% 20$ stress\&f=false. 
47. Sarwono, \& Purwono, 2006. Hubungan Masa Kerja Dengan Stress Kerja Pada Pustakawan Perpustakaan Universitas Gadjah Mada Yogyakarta. Berkala Ilmu Perpustakaan dan Informasi, 1.

48. Shute, N., 2009. Having Children Adds Stress to Marriage. www. health.usnews.com/healthnews/blogs/on-parenting/2009/04/13/having-children-adds-stress-to-marriage.

49. Singh, L. B. (2006). The Scourge of Unemployment in India and Psychological Health. India: Ashok Kumar Mittal.

50. Stellman, J. M.,1998. Encyclopedia of Occupational Health and Safety. Geneva: ILO.

51. Stranks, J., 2005. Stress at Work Management and Prevention. United Kingdom: Elsevier ButterworthHeinemann.

52. Stroh, L. K., Northcraft, G. B., \& Neale, N. A.,2008.. Organizational Behavior: a Management Challenge. United States of America: Taylor \& Francis.

53. Sukmono, T., 2013. Hubungan Antara Karakteristik Individu Dengan Tingkat Stres Kerja Perawat Indonesia yang Bekerja di Qatar. Universitas Muhammadiyah Semarang, Semarang. Retrieved from www. digilib.unimus.ac.id/gdl.php?mod=browse\&op=read\&id=jtptunimus-gdl-trisukmono-7019.

54. Swain, S., 2008. Applied Psychology: India Spesific and Cross-cultural Perspective. India: New Vishals.

55. Tawatsupa, B., Lim, L. L., Kjellstrom, T., Seubsman, S. A., \& Sleigh, A. 2010. The Association between Overall Health, Psychological Distress, and Occupational Heat Stress among a Large National Cohort of 40.913 Thai Workers. Global Health Action.

56. Tsuno, Kawakami, Inoue, Ishizaki, Tabata, Tsuchiya, \& Shimazu, 2009. Intragroup and Intergroup Conflict at Work,Psychological Distress and Work Engagement in a Sample of Employees in Japan. Industrial Health.

57. WHO, 2003. Work Organization and Stress. United Kingdom: WHO.

58. WHO, 2010. Health Impact of Psychosocial Hazard at Work: an Overview. 